\title{
Coping Behaviours of Frontline Extension Workers in Akwa Ibom State of Nigeria
}

\section{O.O Ekumankama}

Department of Rural Sociology and Extension, Michael Okpara University of Agriculture, Umudike, P.M.B 7267 Umuahia, Abia State, Nigeria

Email: ooekumankama@yahoo.com

\begin{abstract}
The study determined the coping behaviours exhibited by Akwa Ibom State Agricultural Development Programme (ADP) extension workers in the bid to ease their job-related tension.

The study also highlighted the relationship between selected personal characteristic and coping behaviours of the extension personnel. Data for the study were obtained from 88 respondents who were randomly selected. Mean score, and correlation statistic were the statistical tools employed in analyzing the data. The findings show that the extension agents (BESs) in Akwa Ibom State ADP dealt rarely with the job-related tension by using many of the coping behavioural variables such as talking with friends, spouse and relatives, involvement in religious activities, seeking professional help among others respectively. Level of formal education, household size, and extension experience of EAs were strong predicators of coping behaviours. Age and extension experience of BEAs and BESs were significantly associated with coping behaviours. It was concluded that the socio-economic characteristics of the extension agents influenced their coping behavior. Necessary recommendations such as improving extension agents' education and working experience as well as constant training for capacity enhancement were made among others.
\end{abstract}

Keywords- Coping Behaviour, Frontline Extension Workers, Akwa Ibom State, Nigeria.

\section{INTRODUCTION}

Field extension workers deals with wide varieties of constituencies and programme requirements. Dealing with organizational and public demands will make these extension educators to feel tense up. Extension must be address the issue of job-related tension to attract and retain leading professionals, if it intends to continue as a principal provider of non formal educational programmes (Goering, 1991, Place and Jacob, 2001). Subsequently, determining the behaviors exhibited by frontline extension staff to cope with job-related tension will provide policy makers, www.ijeab.com programme administrators, and development practitioners at all levels with relevant information they need for improvement and future planning.

Tension is part and parcel of work. However, the worker's ability to cope with it is what makes the difference between fulfilling and unfulfilled job. Coping is an individual action that is learned from one's reference group, such as one's colleagues. Each individual has to manage his own coping; it is not something that can be done by others, no matter how supportive they may be. Ability to cope with tension is important in extension work. Coping well with tension plays a large part in achieving a sense of well-being at all levels (Long, 1988; Goering , 1991 Place and Jacob,2001). Every worker has to discover for himself effective methods or ways of coping with job-relate tension that work for him and put these into practice. This study will help to identify coping strategies used by extension personnel to ease jobrelated tension. This will form an information pool which extension workers will use to cope rationally with tension arising from their work. Extension administrator will also use the information to help their subordinates to cope well with work-related tension.

Human beings continually assess what is happening in their environment because different behavioural situations demand different coping strategies (Bernard and Bandler, 1998, Oranye, 2002). In coping with tension with tension arising from extension work, some personal characteristics having positive or negative influences may come into play. There is need to identify the personal characteristics of extension staff that effect (Favour or disfavour) their abilities in coping with job-related tension. Herein lies the importance of this study.

The study investigated the behaviours exhibited by frontline extension workers in the bid to deal with their job-related tension. The relationship between selection personal characteristics and coping behaviours of these extension workers was explored. 


\section{MATERIALS AND METHODS}

Akwa Ibom State of Nigeria was the study area. The population of the study was made up of frontline extension workers that included the block extension supervisors (BESs), block extension agents (BEAs), and extension agents (EAs) in Akwa Ibom state ADP (AKADEP). AKADEP has 6 agricultural zones, viz, Abak, Eket, Etinan, Ikot Ekpene, Oron and Uyo consisting of 9, 7, 4, 8, 4 and 8 blocks, respectively. The blocks are made up of 59, 40, 27, 63, 23 and 62 circles, respectively. Altogether, AKADEP has 6 agricultural zones, 40 blocks and 274 circles (Okpongete, 2000; Umoh, 2003).

Multi-stage random sampling procedure was used in the selection of the agricultural zones, blocks and circles. The first stage involved simple random selection of two agricultural zones. Ikot Ekpene and Uyo zones were selected. The second stage involved simple random sampling of seven blocks from each of the agricultural zones. The BESs and BEAs whose blocks were selected served as respondents. The third stage involved simple random selection of five circles from each of the blocks. The EAs whose circles were selected served as respondents. This gave a total of 14 BESs, 14 BEAs and 70 EAs. On the whole, a total of 98 respondents made up the sample size for the study. However, 88 questionnaires (14, 12 and 62 questionnaires from BESs, BEAs and EAs, respectively) where found suitable for the study.

Three sets of questionnaires were used to elicit information from EAs, BESs and BESs.

Questionnaires for EAs, BEAs and BESs designed to elicit information on their personal characteristics and job-related tension coping behaviors.

The coping behaviours of the frontline extension workers were measured by asking each of them to indicate the degree of their agreement with each of the 28 different coping behavioral/attitude statements or items on a five point likert-type scale. The five point on the scale were weighted according to the degree of agreement as follows: 1=Not at all, 2=Rarely, 3=Sometimes 4=Often, and $5=$ Always. The mean degree of agreement for each of the 28 different coping behavioral/attitude score of the group by the member of the respondents. The coping behavioral/attitude level for each group of respondents was computed by dividing the grand mean coping behaviourial/attitude score of the group by the number of the different coping behaviourial/attitude statements (28).

Mean scores and correlation statistic were utilized for data analysis. The correlation statistic was used to test the relationship between selected personal characteristics and the job related tension coping behaviourial variable of the frontline extension workers. The level of probability that www.ijeab.com was accepted as indication of a statistically significant relationship for correlation analysis was at 0.05

\section{Coping behaviours of extension agents}

Data in Table 1 indicate the means of the job-related tension coping behaviours for the EAs. Involvement in religious activities was the first most frequently used coping behavioural variable in dealing with job-related tension by EAs. Prioritizing work and sticking to priorities was the second most frequently exhibited coping behaviours by EAs. The table reveals that talking with friends was the third most frequently used coping behavioural variable in dealing with job-related tension by EAs. Prioritizing tasks and cutting out unnecessary work are actions that can be taken by management to help workers cope with job-related tension thereby promoting better working conditions in the organization (Mullins, 2007).

The grand mean coping behavioural score for EAs was 68.32. The coping behavioural level for EAs was 2.00 implying that majority of the EAs dealt rarely with jobrelated tension by using many of the coping behavioural variables.

\section{Coping behavioural of block extension agents}

Table 1 shows the means of the job-related tension coping behaviours for the BEAs.

Talking with friends was the first most frequently exhibited coping behavior by BEAs. Involvement in religious activities was the second most frequently exhibited coping behavior by BEAs. Involvement in organized groups and talking with relative were the third most frequently used coping behavioural variables by BEAs. The ability to hold good-quality conversation is becoming a core individual and organizational skill. Conversations are intrinsically creative and roam freely across corporate gossip, work projects and personal issues. Conversations are a defence against stress/tension and other mental health problems. Employees with good social relationship at work are much less likely to be anxious or stressed or tensed up (Reeves, 2003). A growing number of organizations are introducing an email- free day to encourage workers to use the telephone or walk across the corridor to talk more with one another (Mullins, 2007).

Date in Table 1 show that the grand mean coping behavioural score for BEAs was 65.67.

The coping behavioural level for BEAs was 2.00 implying that majority of the BEAs dealt rarely with Job-related tension by using many of the coping behavioural variables.

Coping behaviours of block extension supervisors 
Setting realistic goal for my work was the first most frequently used coping behavioural variable by BESs (Table 1). Date in Table 1 reveal that involvement in religious activities, and prioritizing work and sticking to priorities were the second and the third most frequently exhibited coping behaviours by BESs, respectively.
The grand mean coping behavioural score for BESs was 68.64. The coping behavioural level for the BESs was 2.45 approximately 2.00 implying that majority of the BESs dealt rarely with job-related tension by using many of the coping behavioural variables .

Table.1: coping behaviours exhibited by frontline extension workers

\begin{tabular}{|l|l|l|l|}
\hline Coping Behaviour & \multicolumn{2}{|l|}{ X } \\
\hline & EAs & BEAs & BES \\
\hline Talking with spouse & 2.82 & 2.83 & 3.43 \\
\hline Talking with Friends & 3.53 & 3.83 & 3.43 \\
\hline Involvement in religion activities & 3.61 & 3.75 & 3.79 \\
\hline Involvement in organized groups & 3.40 & 3.42 & 3.21 \\
\hline Smoking & 1.26 & 1.00 & 1.14 \\
\hline Going out to have a drink & 1.66 & 1.17 & 1.43 \\
\hline Working around the house & 2.16 & 1.67 & 2.00 \\
\hline Finding activities that will take mind off & 2.44 & 2.17 & 2.50 \\
\hline Going for shopping & 2.40 & 2.25 & 2.21 \\
\hline Seeking professional help & 2.87 & 2.75 & 3.07 \\
\hline Going on tranquilizers & 1.74 & 2.08 & 1.14 \\
\hline Changing of eating habits & 1.58 & 1.92 & 1.57 \\
\hline Going on other drugs & 1.44 & 1.17 & 1.50 \\
\hline Just get away from everybody & 1.66 & 1.25 & 1.57 \\
\hline Gambling & 1.31 & 1.00 & 1.57 \\
\hline Talking with relatives & 2.81 & 3.42 & 3.07 \\
\hline Tight with money & 2.16 & 2.17 & 2.21 \\
\hline Over-spending & 2.10 & 1.67 & 2.00 \\
\hline Visiting favourite places & 2.57 & 2.25 & 2.71 \\
\hline Savouring special relationships & 2.48 & 2.00 & 1.79 \\
\hline Leaving problem at work & 2.42 & 3.00 & 2.36 \\
\hline Searching out relevant information to deepen understanding & 2.92 & 2.67 & 3.36 \\
\hline Watching videos/film & 2.77 & 2.92 & 2.71 \\
\hline Listening to music & 2.97 & 2.75 & 3.14 \\
\hline Setting realistic goals for my work & 3.50 & 3.33 & 3.86 \\
\hline Prioritizing work and sticking to priorities & 3.57 & 3.33 & 3.50 \\
\hline Engaging in other income generating activities e.g motor cycle taxing. & 1.36 & 1.33 & 1.57 \\
\hline Refusing to become over stretched by another person's \\
expectations & & & \\
\hline Mean $X$ Copistic & 2.82 & 2.58 & 2.79 \\
\hline & & & \\
\hline
\end{tabular}

Grand Mean (X) Coping Behaviour Score: (a) EAs $=68.32$ (b)BEAs $=65.67$ (c) BESs $=68.64$

Coping behavior level: (a) EAs $=2.44 \approx 2.00$ (b) $\mathrm{BEAs}=2.35 \approx 2.00 \quad$ (c) $\mathrm{BESs}=2.45 \approx 2.00$

Relationship between selected personal characteristics and job-related tension coping behaviours of frontline extension workers

Information on the relationship between selected personal characteristics and job-related tension coping behaviours of frontline extension workers are presented under hypothesis
1 to 3. Age, level of formal education, household size and extension experience of frontline extension workers were tested for their relationship with job-related tension coping behaviours using Pearson correlation. 
Relationship between selected personal characteristics and job-related tension coping behaviours of extension agents

The first hypothesis states that there is no significant relationship between selected personal characteristics and job-related tension coping behaviours of extension agents. Data in Table 2 indicate the relationship between selected personal characteristics and job-related tension coping behaviours of EAs.

The table shows that the level of formal education of EAs was negatively and significantly correlated with their going out to have a drink ( $\mathrm{r}=0.42)$, going on other drugs e.g. antidepressants sleeping tablets and so on, and engaging in other income generating activities e.g motor cycle taxing $(\mathrm{r}=-0.27)$, respectively. The implication of this finding is that the higher the level of formal education received by the EAs, the less they dealt frequently with job related tension by going out to have a drink, going on others e.g. antidepressants, and sleeping tablets among others, and engaging in other income generating activities e.g. motor cycle taxing and thus, the less they coped effectively with job-related tension.

The table further reveals that household size of EAs was positively and significantly correlated with talking with spouse $(r=0.25)$, implying that the larger the household size of the EAs, the more they dealt frequently with job-related tension by talking with their respective spouses and hence, the more they coped well with job-related tension. Extension experience of EAs was positively and significantly correlated with being tight with money $(\mathrm{r}=0.27)$, meaning that the more experience the EAs acquired in extension work, the more they dealt frequently with job-related tension by being tight with money and thus, the more they coped better with job-related .

Relationship between selected personal characteristics and job -related tension coping behaviours of block extension agents in Akwa Ibom State ADP.

Table 2 reveals that extension experience of BEAS was positively and significantly correlated with seeking professional help $(r=0.71)$, going on tranquilizers $(r=0.65)$, setting realistic goals for my work $(\mathrm{r}=0.61)$, and prioritizing work and sticking to priorities $(\mathrm{r}=0.61)$, respectively. The implication of this finding is that the more experience the BEAs acquired in extension work, the less they dealt frequently with job-related tension by being tight with money and thus, the less the coped well with the job-related tension.

Age of BEAs was positively and significantly correlated with talking with spouse ( $\mathrm{r}=0.67)$,
Implying that the older the BEAs, the more they dealt frequently with job-related tension by talking with their spouses and hence, the more the coped effectively with jobrelated tension. Age of BEAs was negatively and significantly correlated with seeking professional help $(r=0.66)$, and changing of eating habits $(r=0.61)$ this findings implies that the older the BEAs, the less they dealt frequently with job-related tension by seeking professional help, and changing of eating habits and thus, the less they coped well with job-related tension.

The table further indicates that household size of BEAs was negatively and significantly correlated with being tight with money $(r=0.64)$. The implication of this finding is that the larger the household size of the BEAs, the less they dealt frequently with job-related tension by being tight with money and thus, the less they coped effectively with jobrelated tension. 
Table 2: Relationship between selected personal characteristics and job-related tension coping behaviours of front-line extension workers

\begin{tabular}{|c|c|c|c|c|c|c|c|c|c|c|c|c|c|c|c|c|c|c|c|c|c|c|c|c|c|c|c|c|}
\hline $\begin{array}{l}\text { Personal } \\
\text { characteri } \\
\text { stics }\end{array}$ & $\mathrm{Y} 1$ & $\begin{array}{l}\mathrm{Y} \\
2\end{array}$ & $\begin{array}{l}\mathrm{Y} \\
3\end{array}$ & Y4 & $\begin{array}{l}\mathrm{Y} \\
5\end{array}$ & Y6 & $\begin{array}{l}\mathrm{Y} \\
7\end{array}$ & $\begin{array}{l}\mathrm{Y} \\
8\end{array}$ & $\begin{array}{l} \\
9\end{array}$ & $\begin{array}{l}\text { Y1 } \\
0\end{array}$ & $\begin{array}{l}\text { Y1 } \\
1\end{array}$ & $\begin{array}{l}\mathrm{Y} 1 \\
2\end{array}$ & $\begin{array}{l}\mathrm{Y} 1 \\
3\end{array}$ & $\begin{array}{l}\mathrm{Y} 1 \\
4\end{array}$ & $\begin{array}{l}\text { Y1 } \\
5\end{array}$ & $\begin{array}{l}\text { Y1 } \\
6\end{array}$ & $\begin{array}{l}\text { Y1 } \\
7\end{array}$ & $\begin{array}{l}\text { Y1 } \\
8\end{array}$ & $\begin{array}{l}\text { Y1 } \\
9\end{array}$ & $\begin{array}{l}\text { Y2 } \\
0\end{array}$ & $\begin{array}{l}\mathrm{Y} 2 \\
1\end{array}$ & $\begin{array}{l}2 \\
2\end{array}$ & $\begin{array}{l}2 \\
3\end{array}$ & $\begin{array}{l}\mathrm{Y} 2 \\
4\end{array}$ & $\begin{array}{l}\mathrm{Y} 2 \\
5\end{array}$ & $\begin{array}{l}\mathrm{Y} 2 \\
6\end{array}$ & $\begin{array}{l}\mathrm{Y} 2 \\
7\end{array}$ & $\begin{array}{l}\mathrm{Y} 2 \\
8\end{array}$ \\
\hline $\begin{array}{r}\text { Age (a) } \\
\text { (b) } \\
\text { (c) }\end{array}$ & $\begin{array}{l}.23 \\
.67 \\
* \\
.41\end{array}$ & $\begin{array}{l}.0 \\
2 \\
- \\
1 \\
8 \\
- \\
0 \\
2\end{array}$ & $\begin{array}{l}.0 \\
2 \\
- \\
0 \\
0 \\
- \\
0 \\
9\end{array}$ & $\begin{array}{l}- \\
07 \\
.07 \\
- \\
15\end{array}$ & $\begin{array}{l}- \\
0 \\
1 \\
\mathrm{a} \\
.0 \\
2\end{array}$ & $\begin{array}{l}- \\
0.2 \\
0 \\
- \\
0.9 \\
- \\
13\end{array}$ & $\begin{array}{l}- \\
0 \\
8 \\
1 \\
3 \\
.1 \\
1\end{array}$ & $\begin{array}{l}- \\
1 \\
2 \\
.2 \\
4 \\
.0 \\
2\end{array}$ & $\begin{array}{l}.0 \\
3 \\
- \\
2 \\
5 \\
1 \\
0\end{array}$ & $\begin{array}{l}.09 \\
.66 \\
* \\
- \\
00\end{array}$ & $\begin{array}{l}- \\
10 \\
- \\
23 \\
- \\
10\end{array}$ & $\begin{array}{l}.16 \\
- \\
61 \\
* \\
.12\end{array}$ & $\begin{array}{l}.15 \\
36 \\
- \\
24\end{array}$ & $\begin{array}{l}- \\
14 \\
- \\
11 \\
- \\
37\end{array}$ & $\begin{array}{l}- \\
20 \\
\mathrm{a} \\
.13\end{array}$ & $\begin{array}{l}- \\
04 \\
- \\
09 \\
.54 \\
*\end{array}$ & $\begin{array}{l}- \\
.16 \\
- \\
14 \\
- \\
14\end{array}$ & $\begin{array}{l}.12 \\
.07 \\
- \\
09\end{array}$ & $\begin{array}{l}.11 \\
- \\
15 \\
- \\
35\end{array}$ & $\begin{array}{l}.07 \\
.05 \\
.04\end{array}$ & $\begin{array}{l}.07 \\
- \\
27 \\
- \\
11\end{array}$ & $\begin{array}{l}- \\
02 \\
.58 \\
.25\end{array}$ & $\begin{array}{l}- \\
05 \\
.19 \\
.18\end{array}$ & $\begin{array}{l}- \\
08 \\
.10 \\
.11\end{array}$ & $\begin{array}{l}.11 \\
.04 \\
- \\
10\end{array}$ & $\begin{array}{l}- \\
08 \\
- \\
07 \\
- \\
20\end{array}$ & $\begin{array}{l}.10 \\
- \\
20 \\
46\end{array}$ & $\begin{array}{l}.17 \\
.34 \\
- \\
14\end{array}$ \\
\hline $\begin{array}{l}\text { Level of } \\
\text { (a) } \\
\text { Formal } \\
\text { (b) } \\
\text { Education } \\
\text { (c) }\end{array}$ & $\begin{array}{l}.01 \\
.45 \\
.21\end{array}$ & $\begin{array}{l}- \\
1 \\
6 \\
- \\
4 \\
3 \\
- \\
2 \\
3\end{array}$ & $\begin{array}{l}.0 \\
9 \\
.4 \\
2 \\
\\
.0 \\
5\end{array}$ & $\begin{array}{l}.23 \\
- \\
57 \\
- \\
06\end{array}$ & $\begin{array}{l}- \\
0 \\
1 \\
a \\
.0 \\
6\end{array}$ & $\begin{array}{l}- \\
42 \\
* \\
- \\
47 \\
.25\end{array}$ & $\begin{array}{l}- \\
1 \\
5 \\
- \\
0 \\
9 \\
.0 \\
7\end{array}$ & $\begin{array}{l}.1 \\
6 \\
.0 \\
3 \\
\\
.4 \\
6\end{array}$ & $\begin{array}{l}- \\
0 \\
6 \\
.2 \\
4 \\
\\
.0 \\
9\end{array}$ & $\begin{array}{l}.01 \\
- \\
19 \\
.09\end{array}$ & $\begin{array}{l}- \\
11 \\
- \\
18 \\
.06\end{array}$ & $\begin{array}{l}- \\
07 \\
- \\
42 \\
.45\end{array}$ & $\begin{array}{l}- \\
27 \\
* \\
- \\
44 \\
.41\end{array}$ & $\begin{array}{l}.24 \\
- \\
23 \\
11\end{array}$ & $\begin{array}{l}- \\
24 \\
\mathrm{a} \\
.11\end{array}$ & $\begin{array}{l}- \\
01 \\
- \\
35 \\
- \\
07\end{array}$ & $\begin{array}{l}- \\
06 \\
- \\
43 \\
- \\
05\end{array}$ & $\begin{array}{l}.11 \\
- \\
11 \\
.16\end{array}$ & $\begin{array}{l}- \\
11 \\
.00 \\
- \\
07\end{array}$ & $\begin{array}{l}- \\
04 \\
.49 \\
- \\
34\end{array}$ & $\begin{array}{l}- \\
11 \\
- \\
17 \\
.12\end{array}$ & $\begin{array}{l}.17 \\
.24 \\
- \\
24\end{array}$ & $\begin{array}{l}- \\
11 \\
- \\
24 \\
- \\
44\end{array}$ & $\begin{array}{l}.09 \\
.00 \\
.13\end{array}$ & $\begin{array}{l}.03 \\
.07 \\
- \\
19\end{array}$ & $\begin{array}{l}- \\
03 \\
.07 \\
.07\end{array}$ & $\begin{array}{l}- \\
27 \\
.11 \\
- \\
17\end{array}$ & $\begin{array}{l}- \\
11 \\
.41 \\
.24\end{array}$ \\
\hline $\begin{array}{l}\text { Househol } \\
\text { d Size (a) } \\
\text { b) } \\
\text { (c) }\end{array}$ & $\begin{array}{l}.25 \\
* \\
.51 \\
.10\end{array}$ & $\begin{array}{l}- \\
0 \\
9 \\
.2 \\
2 \\
.0 \\
3\end{array}$ & $\begin{array}{l}1 \\
4 \\
.0 \\
4 \\
- \\
1 \\
2\end{array}$ & $\begin{array}{l}- \\
09 \\
.03 \\
- \\
36\end{array}$ & $\begin{array}{l}.1 \\
7 \\
\mathrm{a} \\
- \\
1 \\
1\end{array}$ & $\begin{array}{l}.21 \\
- \\
42 \\
- \\
31\end{array}$ & $\begin{array}{l}.0 \\
5 \\
.2 \\
1 \\
- \\
0 \\
5\end{array}$ & $\begin{array}{l}.1 \\
2 \\
.3 \\
9 \\
- \\
1 \\
3\end{array}$ & $\begin{array}{l}.1 \\
5 \\
.2 \\
2 \\
- \\
0 \\
6\end{array}$ & $\begin{array}{l}.13 \\
.21 \\
- \\
03\end{array}$ & $\begin{array}{l}.08 \\
.27 \\
- \\
29\end{array}$ & $\begin{array}{l}.18 \\
.07 \\
- \\
\text { o3 }\end{array}$ & $\begin{array}{l}13 \\
- \\
33 \\
- \\
30\end{array}$ & $\begin{array}{l}.05 \\
- \\
23 \\
.30\end{array}$ & $\begin{array}{l}.06 \\
a \\
- \\
07\end{array}$ & $\begin{array}{l}- \\
06 \\
* \\
.03 \\
.29\end{array}$ & $\begin{array}{l}- \\
17 \\
- \\
64 \\
* \\
.17\end{array}$ & $\begin{array}{l}- \\
02 \\
.03 \\
- \\
20\end{array}$ & $\begin{array}{l}.03 \\
.33 \\
- \\
.09\end{array}$ & $\begin{array}{l}- \\
.08 \\
.35 \\
.00\end{array}$ & $\begin{array}{l}- \\
04 \\
- \\
15 \\
- \\
06\end{array}$ & $\begin{array}{l}- \\
.08 \\
.35 \\
.43\end{array}$ & $\begin{array}{l}- \\
.02 \\
- \\
.05 \\
.23\end{array}$ & $\begin{array}{l}- \\
.08 \\
- \\
.18 \\
- \\
.06\end{array}$ & $\begin{array}{l}- \\
.14 \\
.07 \\
.07\end{array}$ & $\begin{array}{l}- \\
.15 \\
.01 \\
- \\
.25\end{array}$ & $\begin{array}{l}.12 \\
- \\
.35 \\
.26\end{array}$ & $\begin{array}{l}.10 \\
.40 \\
- \\
.02\end{array}$ \\
\hline $\begin{array}{l}\text { Extension } \\
\text { Experienc } \\
\text { e (a) } \\
\text { (b) }\end{array}$ & $\begin{array}{l}.13 \\
.12 \\
.10\end{array}$ & $\begin{array}{l}- \\
.0 \\
9 \\
.2\end{array}$ & $\begin{array}{l}- \\
.0 \\
9 \\
.3\end{array}$ & $\begin{array}{l}- \\
.05 \\
- \\
.04\end{array}$ & $\begin{array}{l}- \\
.0 \\
1 \\
\mathrm{a}\end{array}$ & $\begin{array}{l}.01 \\
- \\
.52 \\
-\end{array}$ & $\begin{array}{l}.1 \\
0 \\
- \\
.1\end{array}$ & $\begin{array}{l}.1 \\
3 \\
.0 \\
0\end{array}$ & $\begin{array}{l}.0 \\
0 \\
.1 \\
7\end{array}$ & $\begin{array}{l}.11 \\
.71 \\
* \\
-\end{array}$ & $\begin{array}{l}.05 \\
.65 \\
- \\
.30\end{array}$ & $\begin{array}{l}- \\
.03 \\
.06 \\
.47\end{array}$ & $\begin{array}{l}.12 \\
- \\
.26 \\
-\end{array}$ & $\begin{array}{l}- \\
.03 \\
- \\
.33\end{array}$ & $\begin{array}{l}.12 \\
\mathrm{a} \\
.32\end{array}$ & $\begin{array}{l}.15 \\
.05 \\
.85 \\
*\end{array}$ & $\begin{array}{l}.27 \\
* \\
- \\
63\end{array}$ & $\begin{array}{l}- \\
.05 \\
- \\
.31\end{array}$ & $\begin{array}{l}.06 \\
- \\
.29 \\
-\end{array}$ & $\begin{array}{l}.09 \\
- \\
.19 \\
-\end{array}$ & $\begin{array}{l}- \\
.10 \\
.33 \\
.04\end{array}$ & $\begin{array}{l}.00 \\
.00 \\
.10\end{array}$ & $\begin{array}{l}- \\
.00 \\
- \\
.48\end{array}$ & $\begin{array}{l}.14 \\
- \\
.20 \\
-\end{array}$ & $\begin{array}{l}.16 \\
.67 \\
* \\
-\end{array}$ & $\begin{array}{l}- \\
.00 \\
.61 \\
*\end{array}$ & $\begin{array}{l}.18 \\
.15 \\
.24\end{array}$ & $\begin{array}{l}.20 \\
.04 \\
- \\
.28\end{array}$ \\
\hline
\end{tabular}




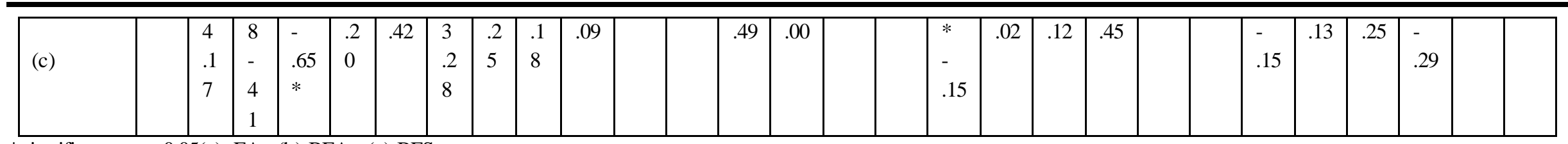

*significant at $\mathrm{p}<0.05$ (a) EAs (b) BEAs (c) BESs

A cannot be computed because at least one of the variables is constant

$$
\text { Key }
$$

$\mathrm{Y}_{1}=$ Talking with spouse

$\mathrm{Y}_{2}=$ Talking with friends

$\mathrm{Y}_{3}=$ Involvement in religious activities

$\mathrm{Y}_{4}=$ Involvement in organized groups

$\mathrm{Y}_{5}=$ Smoking

$\mathrm{Y}_{6}=$ Going out to have a drink

$\mathrm{Y}_{7}=$ Working around the house

$\mathrm{Y}_{8}=$ Finding alternative things to think about

$\mathrm{Y}_{9}=$ Going for shopping

$\mathrm{Y}_{10}=$ Seeking professional

$\mathrm{Y}_{11}=$ Going tranquilizers

$\mathrm{Y}_{12}=$ Changing of eating habits

$\mathrm{Y}_{13}=$ Going on others drugs e.g. anti-depressant, sleeping tablets, etc

$\mathrm{Y}_{14}=$ Just get away from everybody

$\mathrm{Y}_{15}=$ Gambling

$\mathrm{Y}_{16}=$ Talking with relative

$\mathrm{Y}_{16}=$ Tight with moneys

$$
\mathrm{Y}_{17}=\text { Over-spending }
$$

$\mathrm{Y}_{18}=$ Visiting favorite places

$\mathrm{Y}_{19}=$ Savouring special relationship

$\mathrm{Y}_{20}=$ Leaving problems at work

$\mathrm{Y}_{21}=$ Searching out relevant information to deepen understanding

$\mathrm{Y}_{22}=\mathrm{W}$ atching video/films

$\mathrm{Y}_{23}=$ Listening to music

$\mathrm{Y}_{24}=$ Setting realistic goals for my work

$\mathrm{Y}_{25}=$ Prioritizing work and sticking to priorities

$\mathrm{Y}_{27}=$ Engaging in other income generating activities e.g motor cycle taxing

$\mathrm{Y}_{28}=$ Refusing to become over-stretched by another pers on's unrealistic expectations 
Relationship between selected personal characteristics and job-related tension coping behaviours of block extension supervisors in Akwa Ibom State ADP.

The third hypothesis states that there is no significant relationship between selected personal characteristics and job-related tension coping behaviors of block extension supervisors in Akwa Ibom state ADP. Data in Table 2 show the relationship between selected personal characteristics and job-related tension coping behaviours of BEASs in Akwa Ibom state ADP.

Extension experience of BESs was positively and significantly correlated with talking with relatives $(r=0.85)$, This finding implies that the more experience the BESs acquired in extension work, the more they dealt frequently with tension arising from their job by talking with their relatives and hence, the more they coped effectively with job-related tension. Age of BESs was positively and significantly correlated with talking with relatives $(r=0.54)$, meaning that the older the BES, the more they dealt frequently with job-related tension by talking with their relatives and thus, the more they coped well with jobrelated tension.

\section{CONCLUSION AND RECOMMENDATIONS}

The paper concludes that the socio-economic characteristics of extension agents such as their level of formal education, household size, age and extension experience were strong predictors of coping behavior and should be enhanced. Necessary recommendations such as employing those with higher level of formal education; recruiting extension workers based on their practical experience in agriculture constant in-service trainings to enhance coping behavior and job related tension were made.

\section{REFERENCES}

[1] Bernard, J.F., Bandler, R. 1998, parallel circuits for emotional coping behavior: new pieces in the puzzle, The Journal of comparative Neurology, 401:429-436

[2] Goering L.A. 1991, Are women extension professionals more stressed? Journal of extension, 29(3) $1-2$

[3] Long, B.C, 1998, Work-related stress and coping strategies of professional women, Journal of Employment Counseling XXV: 37-44

[4] Mullins L.J. 2007, Management and Organizational Behaviour, Eight Edition, Prentice-Hall, inc, Englewood Cliffs.

[5] Okpongete, M.D. 2000, Akwa Ibom state ADP extension services report for 1999, In; Enyinna,
T.(Ed), proceeding of the $14^{\text {th }}$ Annual Farming Systems Research and Extension Workshop in SouthEastern Nigeria, Pp.92-99

[6] Oranye, N.O. 2002, Health and Illness in society: A Text for Nigerian Students, Afri Towers Ltd., Aba.

[7] Place, N.T, Jacob, S.2001, Stress: professional development needs of extension faculty, journal of Agriculture Education, 42(1): 96-105.

[8] Reeves I.O. 2003, Reality Bites, Management Today, P.35

[9] Umoh, I.O. 2003, Akwa Ibom State ADP extension service report for 2002, AKADEP, Uyo, Pp1-11. 